
$\mathrm{Ke}-21$

\title{
Siti Zubaidah
}

Program Studi Pendidikan Biologi, FMIPA, Universitas Negeri Malang, Jl. Semarang 5 Malang 65145, Indonesia

Email Korespondensi: siti.zubaidah.fmipa@um.ac.id

$\begin{array}{ll}\text { ARTICLE INFO } & \text { ABSTRACT } \\ \begin{array}{l}\text { Article history } \\ \text { Received: August } 2019\end{array} & \begin{array}{l}\text { [Title: The 21st Century Skills Integration on Character Education]. Various cases } \\ \text { carried out by teenagers require serious handling with a variety of strategies, including }\end{array} \\ \begin{array}{l}\text { Accepted: September } 2019 \\ \text { Published: December } 2019\end{array} & \begin{array}{l}\text { through character education. Character education does not mean reducing or replacing } \\ \text { development of intellectual and practical abilities. Character education is carried out }\end{array} \\ \text { Keywords } & \begin{array}{l}\text { integrated into every subject and requires the support of all parties: parents, teachers, } \\ \text { Sharacter education; } \\ \text { 21st Century skills }\end{array} \\ & \begin{array}{l}\text { The development of character can be understood in a model, including the Neo- } \\ \text { Aristotelian Model. Good character education will not only affect well being and good } \\ \text { character, but also good academic ability. Character education is not something new, and }\end{array} \\ & \text { it is not separated from the 21st-century skill-building needed today. }\end{array}$

INFO ARTIKEL
Sejarah Artikel
Dikirim: Agustus 2019
Direvisi: September 2019
Diterima: September 2019
Dipublikasi: Desember
2019

Kata kunci Pendidikan karakter; Keterampilan abad 21

\begin{abstract}
ABSTRAK
Berbagai kasus yang dilakukan para remaja, memerlukan penanganan serius dengan berbagai strategi, diantaranya melalui pendidikan karakter. Pendidikan karakter tidak berarti mengurangi atau menggantikan tujuan pendidikan "tradisional" seperti akumulasi pengetahuan dan pengembangan kemampuan intelektual dan praktis. Pendidikan karakter dilakukan secara terintegrasi ke dalam setiap matapelajaran, dan memerlukan dukungan semua pihak: orangtua, guru, sekolah, tenaga kependidikan, komunitas keseharian siswa dan tentu saja pemerintah. Perkembangan karakter dapat dipahami dalam sebuah model, diantaranya Neo-Aristotelian Model. Pendidikan karater yang dilaksanakan dengan baik, tidak hanya akan berdampak pada well being dan karakter yang baik, namun juga pada kemampuan akademik yang baik. Pendidikan karakter bukanlah sesuatu yang baru, dan tidak terpisah dengan penanaman keterampilan abad ke-21 yang dibutuhkan saat ini.
\end{abstract}

How to Cite this Article? Zubaidah, S. (2019). Pendidikan Karakter Terintegrasi Keterampilan Abad Ke21. Jurnal Penelitian dan Pengkajian Ilmu Pendidikan: e-Saintika, 3(2), 1-24. DOI: https://doi.org/10.36312/e-saintika.v3i2.125

\section{PENDAHULUAN}

Saat ini dunia pendidikan semakin tertantang untuk menyiapkan siswa dalam menghadapi globalisasi yang semakin meningkat, kemampuan penguasaan teknologi dan berbagai keterampilan sesuai perkembangan jaman. Sebagai akibatnya, diperlukan perubahan kurikulum. Pada saat yang sama, perhatian 
terhadap permasalahan-permasalahan karakter juga harus dilakukan, mengingat berbagai suguhan berita yang membuat kita terhenyak. Berbagai kasus seperti tindak kekerasan remaja kepada sesama temannya, perkelahian antar siswa, menurunnya rasa hormat anak pada orangtua dan gurunya, menurunnya rasa tanggung jawab, meningkatnya ketidakjujuran, menurunnya moral, kasus bunuh diri, cyber bullying, dan sebagainya. Sungguh menjadikan bahan pemikiran bagi dunia pendidikan kita.

Karakter bukanlah sesuatu yang dibawa sejak lahir, tidak dapat diharapkan diberikan oleh orangtua sebagai satu-satunya penyedia 'karakter baik', juga tidak dapat 'diajarkan' dari buku teks. Karakter dapat terbentuk oleh seseorang atau sesuatu yang dipengaruhi oleh jumlah waktu interaksi dan konten interaksinya. Semakin banyak waktu yang dihabiskan seorang anak dengan seseorang atau sesuatu, maka akan semakin banyak mereka akan menyerap dan "dibentuk" oleh seseorang atau sesuatu tersebut. "Sesuatu" tersebut dapat berupa TV, video game, ponsel, iPad, atau lainnya. Ada banyak faktor penting yang terlibat dalam pengembangan karakter seseorang, antara lain dari keluarga, komunitas dan sekolah, dan lainnya.

Pendidikan karakter telah lama diwacanakan dan dilaksanakan. Secara eksplisit, di dalam Undang-Undang Republik Indonesia Nomor 20 Tahun 2003 Tentang Sistem Pendidikan Nasional, pada Pasal 1 ayat 1, disebutkan bahwa "Pendidikan adalah usaha sadar dan terencana untuk mewujudkan suasana belajar dan proses pembelajaran agar peserta didik secara aktif mengembangkan potensi dirinya untuk memiliki kekuatan spiritual keagamaan, pengendalian diri, kepribadian, kecerdasan, akhlak mulia, serta keterampilan yang diperlukan dirinya, masyarakat, bangsa dan negara." Nampak bahwa ayat tersebut sarat dengan muatan pendidikan karakter. Pendidikan karakter adalah gerakan nasional untuk menciptakan sekolah yang dapat menumbuhkan generasi muda yang etis, bertanggung jawab, dan peduli dengan memberi contoh dan membelajarkan karakter.

Pendidikan karakter sesungguhnya tidak asing lagi bagi umat beragama. Setiap agama mengutamakan penanaman nilai-nilai karakter yang baik. Umat muslim, memiliki Sang Teladan karakter yaitu Rasulullah SAW. Rasulullah tidak saja memberikan ilmu dalam hal ibadah dan ketaqwaan kepada Allah SWT, namun juga menjadi uswatun hasanah (teladan yang baik) bagi umatnya. Allah bahkan menjamin hal tersebut dengan firman-Nya: "Sesungguhnya telah ada pada diri Rasulullah, suri teladan yang baik bagimu yaitu bagi orang yang mengharap (rahmat) Allah dan (kedatangan) hari kiamat dan dia banyak menyebut nama Allah. (QS. Al Ahzab: 21). Ayat ini merupakan landasan dalam meneladani Rasulullah dalam hal perkataan, perbuatan, dan keadaan Beliau. Rasulullah juga bersabda: “innama bu'itstu liutammima makarimal akhlaq" (Sesungguhnya aku diutus untuk menyempurnakan akhlak yang baik). Tugas Rasulullah adalah menyempurnakan karakter mulia dilandasi kasih sayang dengan empat pilar: shidiq (benar), amanah (jujur, bisa dipercaya), tabligh (menyampaikan), dan fathonah (cerdas).

Banyak kisah yang menunjukkan agungnya budi pekerti Rasulullah yang menjadi teladan bagi umatnya. Rasulullah SAW memiliki beberapa metode dalam mengajarkan banyak hal kepada umatnya termasuk mengajarkan akhlak, 
diantaranya dengan keteladanan, ceramah, berkisah, diskusi, penugasan, dan metode lainnya. Metode yang pertama (keteladanan) menjadi sangat bermakna karena perilaku orangtua atau guru dapat ditiru sang anak dalam kehidupan sehari-hari. Upaya memperbaiki akhlak inilah yang pada pendidikan zaman modern disebut dengan beberapa istilah, diantaranya dengan istilah pendidikan budi pekerti, pendidikan moral, pendidikan nilai, pendidikan karakter, atau istilah lainnya.

\section{PEMBAHASAN}

\section{Karakter dan Asesmennya}

Karakter banyak didefiniskan dengan ragam pengertian yang sebenarnya tidak jauh berbeda. Karakter berasal dari kata Yunani "charaktêr" yang artinya "menandai" seperti "ukiran". Karakter berarti tanda khas dimana satu hal dibedakan dari yang lain, atau kumpulan kualitas yang membedakan satu individu dari yang lain. Dengan kata lain, karakter adalah ciri khas seseorang yang membedakan dari orang lain. Orang yang berkarakter baik adalah individu yang mengetahui mana yang baik, mencintai kebaikan, dan melakukan kebaikan (Pala, 2011). Karakter adalah watak, tabiat, akhlak, adab, atau ciri kepribadian seseorang yang terbentuk dari hasil internalisasi berbagai nilai kebajikan (virtues) yang diyakini dan digunakan sebagai landasan berpikir, bersikap, dan bertindak. Kebajikan bersumber dari sejumlah nilai, moral, dan norma, yang diyakini kebenarannya yang terwujud dalam hubungan-hubungan yang membangun interaksi antara manusia dengan Tuhannya, sesama manusia, lingkungan hidupnya, bangsa dan negaranya, dan dengan dirinya sendiri. Hubunganhubungan itulah yang menimbulkan penilaian baik-buruknya karakter seseorang (Akbar, 2011).

Lapsley dan Narvaez (2006) mengutip beberapa pengertian karakter berikut ini. Karakter adalah "suatu kecenderungan dan minat aktif" yang membuat seseorang "terbuka, siap dan senang terhadap tujuan tertentu atau berperasaan, dingin, tidak mau tahu menahu terhadap orang lain". Karakter terdiri dari seperangkat disposisi dan kebiasaan yang membentuk tindakan dengan cara yang relatif tetap. Karakter adalah pendekatan umum seseoranag terhadap masalah dan tanggung jawab kehidupan sosial, responsif terhadap dunia yang didukung oleh reaksi emosional terhadap kesusahan orang lain, perolehan keterampilan prososial, pengetahuan tentang konvensi sosial dan pembangunan nilai-nilai pribadi; termasuk kapasitas untuk disiplin diri dan empati.

Karakter mencakup semua hal tentang "sikap," "perilaku," "disposisi," "pola pikir," "kepribadian," "temperamen," "nilai-nilai" atau "keterampilan sosial dan emosional". Karakter dapat diartikan sebagai seperangkat sifat atau watak pribadi yang menghasilkan emosi moral tertentu, menunjukkan motivasi dan membimbing perilaku sedangkan pendidikan karakter mencakup semua kegiatan pendidikan yang eksplisit dan implisit yang membantu siswa mengembangkan kekuatan pribadi yang positif yang disebut kebajikan (virtue).

Park dan Peterson (2009) mendefinisikan "karakter yang baik" sebagai suatu kelompok multidimensi dari sifat-sifat moral positif yang dianggap penting dalam kehidupan. Sifat-sifat tersebut tercermin dalam pemikiran, emosi, dan perilaku seseorang. Secara spesifik, telah diidentifikasi enam inti kebajikan-karakteristik 
moral yang dipegang teguh oleh para filsuf dan tokoh-tokoh relijius di dunia. Keenam inti kebajikan ini adalah kebijaksanaan, keberanian, keadilan, kemanusiaan, kesederhanaan, dan transendensi.

Kekuatan karakter muncul dalam berbagai situasi dan konteks dan berkontribusi terhadap kondisi dan fungsi psikologis seseorang. Karakter-karakter tersebut dianggap penting bagi anak-anak ataupun orang dewasa untuk berkembang secara optimal. Perkembangan, praktik, dan penggunaan kekuatan karakter memampukan individu melakukan yang terbaik, karena kekuatan karakter merupakan manifestasi dari potensi individu. Hal ini telah banyak dibuktikan oleh penelitian empiris, yang menunjukkan bahwa anak-anak ataupun orang dewasa yang memiliki kekuatan karakter menghadapi lebih sedikit permasalahan psikologis dan lebih bahagia. Secara umum, kekuatan karakter yang dimiliki oleh anak-anak dan remaja sering dikaitkan dengan perilaku serta kondisi psikososial dan akademik yang baik.

Terdapat berbagai pendapat tentang nilai karakter. Kementerian Pendidikan Nasional telah merumuskan 18 (delapan belas) nilai karakter yang perlu ditanamkan dalam diri siswa sebagai upaya membangun karakter berikut ini:
(1) religius,
(7) mandiri,
(2) jujur,
(8) demokratis,
(13) bersahabat/komunikatif,
(3) toleransi,
(9) rasa ingin tahu,
(14) cinta damai,
(4) disiplin,
(10) semangat kebangsaan
(15) gemar membaca, (nasionalisme),
(5) kerja keras,
(11) cinta tanah air,
(6) kreatif,
(12) menghargai prestasi,
(16) peduli lingkungan,
(17) peduli sosial, dan
(18) tanggung jawab.

Ruark (2018) menyatakan ada 36 nilai karakter yang dapat dilatihkan dalam waktu 36 minggu dengan berbagai teknik. Nilai karakter tersebut adalah berikut ini:
(1) akuntabilitas,
(13) antusiasme,
(25) (bertindak dengan
(2) keberanian,
(14) etika, terencana),
(3) kepedulian,
(15) keadilan,
(26) kegembiraan),
(4) kerja sama,
(16) kesetiaan,
(5) amanah,
(17) keramahan,
(27) kebaikan hati,
(6) kasih sayang
(18) kemurahan hati,
(28) penuh rasa cinta,
(7) kreativitas,
(19) kemurnian hati,
(29) ketekunan,
(30) kesopanan,
(8) dedikasi
(20) rasa bersyukur,
(31) produktivitas,
(pengabdian),
(9) ketabahan,
(21) kerja keras,
(32) tanggung jawab,
(10) disiplin,
(22) kejujuran,
(33) melayani orang lain,
(11) semangat,
(23) kehormatan diri,
(34) ketulusan,
(12) empati,
(24) integritas,
(35) dapat dipercaya, dan
(36) kerelaan hati.

Asesmen atau pengukuran karakter seseorang atau dampak pendidikan karakter cukup sulit karena sifat karakter yang kompleks. Oleh karena itu, kebijaksanaan dan kehati-hatian diperlukan dalam setiap cara untuk mengukur 
karakter secara holistik. Berikut adalah proses yang dapat dilakukan untuk mengases karakter siswa.

1. Mengevaluasi bagaimana budaya dan etos sekolah berkontribusi pada pendidikan karakter. Sekolah dapat merancang dan mengevaluasi seperangkat kriteria karakter apa yang ingin diketahui. Evaluasi semacam itu berdasar pada pengetahuan dan penilaian guru sehingga memberikan bukti tentang kekuatan dan kelemahan sekolah, dengan demikian dapat menyoroti lebih banyak upaya, sumber daya, dan waktu yang harus diarahkan.

2. Mengevaluasi efektivitas, strategi, aktivitas, atau pendekatan dari pendidikan karakter yang dilakukan. Metode yang berbeda, termasuk survei pra-intervensi dan pasca-intervensi, pengamatan dan wawancara dengan guru dan siswa dapat diterapkan untuk mendapatkan bukti tentang dampak dari strategi atau aktivitas pendidikan karakter yang ada. Disarankan untuk mengukur hanya beberapa saja dari komponen karakter dan akan lebih baik untuk melakukan triangulasi data dengan menggunakan lebih dari satu sumber bukti.

3. Melakukan refleksi diri pada karakter dan kebajikan pribadi yang dilakukan oleh siswa sendiri. Hal ini mungkin direkam secara berkala selama perjalanan pendidikan siswa, misalnya dalam jurnal. Bukti yang diperoleh dari teman sebaya, guru dan orang tua akan mendukung proses ini.

Karakter bukanlah sesuatu yang dapat dihitung atau kekal dan tidak bisa berubah, oleh karena itu seringkali diistilahkan juga dengan "kualitas karakter". Berikut ini adalah enam (6) kualitas karakter yang diidentifikasi oleh Bialik, Bogan, Fadel, \& Horvathova (2015) sebagai kualitas karakter yang paling tinggi (Tabel 1). Namun demikian, daftar dalam tabel tersebut belum lengkap dan bukan konsep yang fixed, masih bisa berubah.

Tabel 1. Kualitas Karakter Tertinggi yang Terpilih (Bialik dkk, 2015)

\begin{tabular}{lll} 
No & Kualitas \\
Karakter & Konsep dan Kualitas Karakter Terkait (Bisa Berubah) \\
\hline
\end{tabular}

1 Mindfullness Kebijaksanaan, kesadaran diri, aktualisasi diri (penuh manajemen probadi, observasi, refleksi, kesadaran, kasih perhatian) sayang, syukur, empati, perhatian, pertumbuhan, visi, wawasan, keseimbangan batin, kebahagiaan, kehadiran, keaslian, mendengarkan, berbagi, keterkaitan, saling ketergantungan, kesatuan, penerimaan, keindahan, sensibilitas, kesabaran, ketenangan, keseimbangan, kerohanian, eksistensialitas, kesadaran sosial, kesadaran lintas budaya, dan lain-lain.

\begin{tabular}{|c|c|c|}
\hline 2 & $\begin{array}{l}\text { Curiosity } \\
\text { (Keingintahuan) }\end{array}$ & $\begin{array}{l}\text { Keterbukaan pikiran, eksplorasi, hasrat, pengarahan diri } \\
\text { sendiri, motivasi, inisiatif, inovasi, antusiasme, } \\
\text { keingintahuan, penghargaan, spontanitas, dan lain-lain. }\end{array}$ \\
\hline 3 & $\begin{array}{l}\text { Courage } \\
\text { (Keberanian) }\end{array}$ & $\begin{array}{l}\text { Keberanian, tekad, ketabahan, kepercayaan diri, } \\
\text { pengambilan risiko, kegigihan, ketangguhan, semangat, } \\
\text { optimisme, inspirasi, energi, kekuatan, kegairahan, } \\
\text { keceriaan, humor, dan lain-lain. }\end{array}$ \\
\hline
\end{tabular}




\begin{tabular}{|c|c|c|}
\hline No & $\begin{array}{l}\text { Kualitas } \\
\text { Karakter }\end{array}$ & Konsep dan Kualitas Karakter Terkait (Bisa Berubah) \\
\hline 4 & $\begin{array}{l}\text { Resilience } \\
\text { (Ketangguhan) }\end{array}$ & $\begin{array}{l}\text { Ketekunan, ketabahan, keuletan, inisiatif, keberanian, } \\
\text { disiplin diri, upaya, ketekunan, komitmen, kontrol diri, } \\
\text { harga diri, kepercayaan diri, stabilitas, kemampuan } \\
\text { beradaptasi, berurusan dengan ambiguitas, fleksibilitas, } \\
\text { umpan balik, dan lain-lain. }\end{array}$ \\
\hline 5 & $\begin{array}{l}\text { Ethics } \\
\text { (Etika) }\end{array}$ & $\begin{array}{l}\text { Kemurahan hati, kemanusiaan, integritas, rasa hormat, } \\
\text { keadilan, kesetaraan, keadilan, kebaikan, percaya diri, } \\
\text { inklusif, toleransi, penerimaan, kesetiaan, kejujuran, } \\
\text { kebenaran, kemurnian hati, keaslian, dapat dipercaya, } \\
\text { kesopanan, pertimbangan, pengampunan, kebajikan, } \\
\text { cinta, membantu, kemurahan hati, amal, pengabdian, } \\
\text { rasa memiliki, kewarganegaraan, kesetaraan, dan lain- } \\
\text { lain. }\end{array}$ \\
\hline 6 & $\begin{array}{l}\text { Leadership } \\
\text { (Kepemimpinan) }\end{array}$ & $\begin{array}{l}\text { Tanggung jawab, akuntabilitas, ketergantungan, } \\
\text { keandalan, kesadaran diri, tidak mementingkan diri } \\
\text { sendiri, kerendahan hati, kesederhanaan, keterampilan } \\
\text { hubungan, refleksi diri, inspirasi, organisasi, delegasi, } \\
\text { bimbingan, komitmen, kepahlawanan, karisma, } \\
\text { membimbing, keterlibatan, keteladanan, orientasi-tujuan, } \\
\text { fokus, orientasi hasil, ketepatan, efisiensi, negosiasi, } \\
\text { konsistensi, sosialisasi, kecerdasan sosial, } \\
\text { keanekaragaman, kesopanan, dan lain-lain. }\end{array}$ \\
\hline
\end{tabular}

Pada bagian berikut diberikann penjelasan sekilas tentang enam (6) kualitas karakter tertinggi menurut Bialik dkk. (2015), beserta ringkasan cara mempelajari dan mengasesnya. Hal-hal berikut hanya contoh saja. Penilaian setiap kualitas karakter dapat dikembangkan sesuai kebutuhan.

1. Mindfullness

Mindfulness (penuh pengertian) dapat diartikan sebagai kesadaran yang muncul melalui perhatian pada tujuan, dan tanpa menghakimi terhadap pengalaman dari waktu ke waktu. Hal yang penting untuk dipahami adalah bahwa seseorang yang mengajarkan mindfullness juga mempraktikkannya dalam kehidupannya sendiri, karena jika tidak melakukan demikian maka keaslian dan keefektifannya kemungkinan akan berkurang.

Mindfullness dapat dimiliki oleh siswa ketika guru secara eksplisit berdiskusi dengan siswa untuk mengatasi kesalahpahaman. Instrumen yang dapat digunakan untuk mengases mindfullness adalah kuisioner laporan diri, yang mempertimbangkan berbagai segi perhatian. Siswa dapat dipicu untuk merefleksikan diri mereka dan pengalaman mereka sendiri.

2. Curiosity

Curiosity (keingintahuan) merupakan kesenangan bawaan terhadap pembelajaran dan pengetahuan, tanpa mengharapkan keuntungan apa pun. 
Curiosity juga dapat diartikan sebagai dorongan internal (homeostatis) serta respons terhadap isyarat eksternal (stimulus yang ditimbulkan). Sebuah studi telah menemukan bahwa semakin besar rasa ingin tahu, semakin banyak sumber daya (waktu) yang rela dihabiskan siswa untuk mencari tahu, dan semakin besar kemungkinan mereka akan mengingat informasi itu kelak. Selain itu, rasa ingin tahu yang lebih tinggi juga berkorelasi dengan aktivasi area otak yang lebih tinggi seperti kesalahan prediksi, dan memori.

Pembelajaran yang hanya memberikan informasi kepada siswa tidak akan efektif dalam memunculkan curiosity. Oleh karena itu, teknik yang bisa dilakukan guru adalah menyajikan hal-hal yang bersifat kontradiktif, dan atau melalui pembelajaran berbasis penyelidikan dan pembelajaran berbasis masalah. Selain itu, curiosity terkait erat dengan dorongan intrinsik siswa untuk memahami dunia di sekitar mereka sehingga proses pembelajaran yang terlalu terkendali oleh guru tidak menyisakan ruang bagi siswa dalam mendorong curiosity. Teknik lain yang bisa dilakukan guru adalah menumbuhkan kesadaran siswa bahwa proses belajar yang dilakukan ini adalah penting bagi diri mereka.

Pengukuran curiosity secara langsung cukup sulit dilakukan karena beberapa penelitian telah menunjukkan setiap tes yang dilakukan menjadi bias terhadap pengukuran curiosity. Cara yang sesuai untuk mengases curiosity adalah menggunakan kuesioner. Biasanya kuesioner berisi tentang keterlibatan dalam pembelajaran. Misalnya sejauh mana siswa tampak termotivasi secara intrinsik, dan seberapa jauh mereka mendorong diri mereka sendiri.

3. Courage

Courage (keberanian) merupakan kemampuan untuk bertindak terlepas dari ketakutan atau ketidakpastian, dalam situasi berisiko atau ketika dirinya merasa lemah. Keberanian diperlukan untuk semua individu baik dalam kehidupan profesional dan pribadi. Pengambilan risiko lebih tinggi pada remaja daripada anak-anak atau orang dewasa, dan lebih tinggi pada pria dibandingkan wanita. Keberanian dapat dianggap sebagai pengalaman subjektif, di mana seseorang mengatasi rasa takut dan memilih untuk mengambil tindakan dalam menghadapi ketidakpastian. Ciri-ciri courage termasuk keterbukaan terhadap pengalaman, kesadaran, dan ciri-ciri evaluasi diri seperti self-efficacy.

Courage dapat dibelajarkan di dalam sekolah maupun di luar sekolah. Courage dibutuhkan di kelas bagi guru dan siswa untuk mengatasi rasa takut, mempelajari konsep dan keterampilan baru. Pengambilan risiko yang signifikan terbukti meningkatkan kompetensi, imajinasi, kepercayaan diri, dan kecerdikan siswa. Untuk mengembangkan courage, seorang guru dapat menggunakan empat taktik: (1) berperan sebagai teladan pengambil risiko, (2) mengambil pelajaran dari kesalahan sebagai peluang untuk belajar, (3) memberi kebijakan penilaian yang memaafkan kesalahan dan mendorong perbaikan, dan (4) berdiskusi tentang kesalahan yang membuahkan hasil yang sukses.

Contoh membelajarkan courage di luar sekolah dengan program belajar informal dalam waktu tertentu untuk membangun hubungan, tantangan fisik dan perolehan keterampilan. Kualitas pengalaman belajar informal ini, bersama dengan dukungan sosial dapat menumbuhkan keberanian, dengan memastikan bahwa siswa "dilihat, didengar, dan dihargai." Program-program semacam itu dapat 
meningkatkan self-efficacy, dan mendorong siswa untuk membuat pilihan yang baik dan terlepas dari ketakutan. Cara mengukur courage berdasarkan tanggapan siswa terhadap studi kasus dan tugas penilaian situasional.

\section{Resilience}

Resilience (ketangguhan) merupakan kemampuan atau serangkaian kualitas yang memungkinkan seseorang untuk mengatasi rintangan. Pengertian lain dari resilience adalah proses dinamis yang mencakup adaptasi positif yang signifikan dalam menghadapi kesulitan. Tiga faktor utama yang telah diidentifikasi di sekolah, masyarakat, dan sistem dukungan sosial yang secara positif mempengaruhi ketangguhan remaja adalah: hubungan yang terjaga, komunikasi yang baik, dan peluang untuk keterlibatan dan partisipasi yang bermakna.

Situasi pembelajaran di kelas dapat menentukan resilience siswa. Oleh karena itu, cara tepat mendorong resilience adalah dengan meningkatkan tujuh sifat berikut: perhatian dan hubungan, pro-sosialitas dan dukungan, keterlibatan, inklusivitas, kolaborasi, pemberdayaan, dan fokus pada pembelajaran. Dengan mengajarkan resilience kepada semua siswa, guru tidak hanya melindungi siswa yang diidentifikasi sebagai "berisiko" tetapi juga membekali setiap siswa untuk menghadapi kesulitan yang harus mereka atasi dalam kehidupan mereka. Kehidupan dalam keluarga dan keterlibatan masyarakat telah diidentifikasi sebagai dua faktor lingkungan lain yang memengaruhi resilience anak. Semakin banyak faktor protektif yang dimiliki anak, semakin besar kemungkinan mereka untuk berhasil ketika dihadapkan dengan tantangan.

Pengukuran resilience menggunakan berbagai metode dengan berfokus pada enam domain yaitu keamanan, pendidikan, persahabatan, bakat dan minat, nilainilai positif dan kompetensi sosial. Pengukuran resilience perlu dilakukan secara berkelanjutan.

\section{Ethics}

Ethics (etika) adalah norma atau aturan yang dipakai sebagai pedoman dalam berperilaku di masyarakat bagi seseorang terkait dengan sifat baik dan buruk. Etika dikaitkan dengan kesusilaan dan perilaku manusia di dalam pergaulannya dengan sesama yang menyangkut prinsip dan aturan tentang tingkah laku yang benar. Etika adalah kewajiban dan tanggungjawab moral setiap orang dalam berperilaku di masyarakat.

Penelitian menunjukkan bahwa metode drill tidak terlalu efektif, namun sebaiknya pembelajaran etika otonomi siswa jauh lebih efektif. Salah satu cara untuk memberi siswa otonomi dengan keputusan etis adalah melalui pembelajaran demokratis, yaitu siswa bertanggung jawab secara kolektif dalam membuat keputusan. Tanggung jawab ini melibatkan mereka dalam peran yang sesuai dengan usia namun yang lebih penting membutuhkan perilaku etis. Pembelajaran etika juga dapat dilakukan dengan mengintegrasikan ethics ke dalam kurikulum, misalnya melalui serangkaian studi kasus dilema etis.

Cara mengases ethics dengan mengkategorikan penalaran siswa terhadap berbagai pertanyaan etis. Seseorang dapat ditempatkan pada suatu titik dalam kerangka yang lebih besar dari pengembangan penalaran moralnya.

6. Leadership 
Leadership (kepemimpinan) tidak selalu diidentikkan dengan organisasi yang di dalamnya terdapat bawahan yang dipandang sebagai pengikut dan pemimpin yang dipandang sebagai ahli yang berusaha memaksimalkan kontrol mereka dan memotivasi bawahan untuk bertindak dengan cara tertentu menuju tujuan organisasi. Leadership bukan tentang satu individu, tetapi serangkaian proses, praktik dan interaksi, serta kontrol penuh. Leadership dapat diartikan sebagai proses relasional dan etis dari orang-orang yang bersama-sama berusaha mencapai perubahan positif. Model leadership relasional ini mencakup dimensi menjadi inklusif, memberdayakan, bertujuan, beretika, dan berorientasi pada proses.

Leadership tidak boleh hanya ditujukan untuk siswa yang diidentifikasi berbakat saja, tetapi harus menjadi bagian dari semua pendidikan karena leadership sejati tumbuh dari proses kelompok. Dengan demikian, memberikan contoh pemimpin yang sukses tidak akan membantu, namun fokusnya adalah pada proses kepemimpinan dan menggunakan pengalaman kepemimpinan bersama dengan diskusi seputar pengalaman-pengalaman yang memungkinkan siswa untuk memahami bagaimana kelompok berfungsi dan membangun kapasitas yang relevan dalam diri mereka sendiri. Siswa harus didorong untuk mengambil peran kepemimpinan dan meningkatkan metakognitif tentang pengalaman mereka bekerja dengan kelompok.

Pengukuran leadership dapat dilakukan dengan menggunakan kuesioner dengan berdasarkan gagasan bahwa leadership yang efektif adalah menjadi diri sendiri, dan menilai berbagai dimensi (intelektual, manajerial, dan sosialemosional). Cara lain yang bisa digunakan untuk mengases kepemimpinan melalui laporan diri, evaluasi guru, dan penilaian situasional.

\section{Karakter dan Keterampilan Abad Ke-21}

Perkembangan dunia yang dimediasi teknologi sedemikian pesat membutuhkan perpaduan keterampilan yang berbeda dengan masa lalu, siswa tidak hanya harus memiliki keterampilan yang kuat di bidang-bidang seperti seni bahasa, matematika dan sains, tetapi mereka juga harus mahir dalam keterampilan seperti berpikir kritis, pemecahan masalah, dan kolaborasi, serta kualitas karakter yang kuat seperti kegigihan, ketekunan, keingintahuan dan inisiatif (World Economic Forum, 2015). Hal tersebut memerlukan suatu framework untuk antisipasi di berbagai bidang, termasuk bidang pendidikan seperti Center For Curriculum Redesign (2015) yang telah mendesain framework pembelajaran menggunakan pendekatan holistik pada empat dimensi pendidikan yaitu pengetahuan, keterampilan, karakter, dan metakognisi (Gambar 1). 


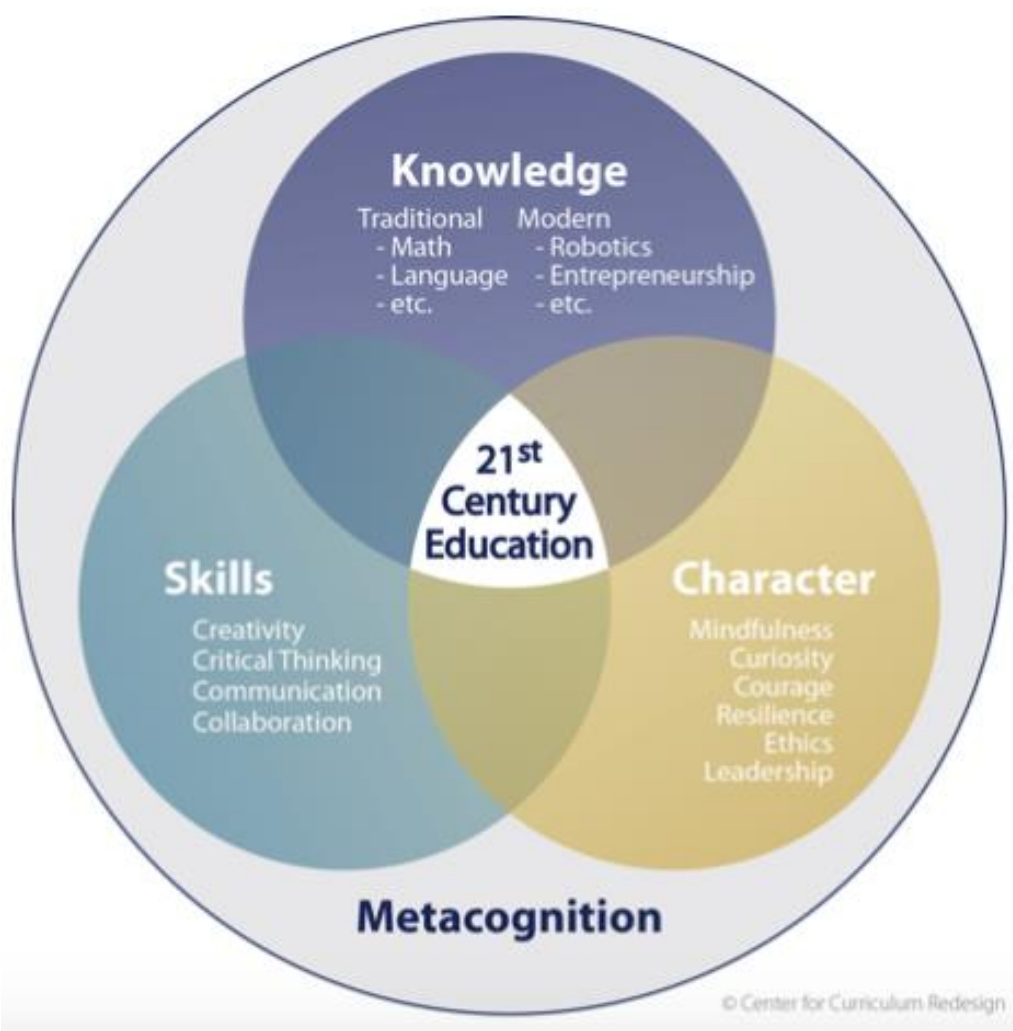

Gambar 1. Dimensi Pendidikan pada Abad 21

Sejak awal tujuan pendidikan adalah membentuk karakter yaitu menumbuhkan siswa yang percaya diri, menjadi seseorang yang sukses, berkontribusi pada komunitas, dan melayani masyarakat sebagai warga negara yang beretika. Karakter pendidikan adalah tentang perolehan dan penguatan kebajikan (kualitas), nilai-nilai (cita-cita dan konsep), dan kapasitas untuk membuat pilihan-pilihan bijak dalam kehidupan yang menyeluruh. Faktanya, hasil studi yang dilakukan menemukan bahwa masalah lingkungan, korupsi, terorisme, ketimpangan pendapatan merupakan variabel-variabel yang sering dihadapi masyarakat saat ini. Oleh karena itu perlu mengembangkan pendidikan karakter di sekolah.

Karakter adalah suatu dimensi dari kehidupan yang membantu seseorang untuk bertahan, memperlakukan orang lain dengan bermartabat, dan memajukan masyarakat. Pada abad ke-21 yag berpotensi menurunkan nilai karakter, dunia pendidikan perlu mengembangkan karakter (Elias, 2014; Fink \& Geller, 2013; Johnson, 1999). Siswa perlu difasilitasi dengan pembelajaran yang disengaja untuk mengembangkan kualitas karakter dan kemampuan akademiknya. Siswa memerlukan pendampingan yang kuat untuk memenuhi kemampuan menghadapi abad ke-21 dengan karakter yang baik untuk menjadi sukses saat lulus dari sekolah, perguruan tinggi, masyarakat, dan karirnya kelak.

Hampir semua kekuatan karakter (atau setidaknya beberapa dari komponennya) termasuk ke dalam daftar kompetensi abad 21 yang dibutuhkan untuk mencapai kesuksesan di dunia kerja (Tabel 1). Hampir semua kompetensi tersebut terkait dengan salah satu dari kekuatan karakter, contohnya kompetensi 
kognitif yang berhubungan dengan kegemaran belajar, yang artinya menambah pengetahuan secara sistematis.

Tabel 1. Kekuatan Karakter dan Kompetensi Abad ke-21

\begin{tabular}{|c|c|c|}
\hline $\begin{array}{c}\text { Kelompok Kompetensi } \\
\text { Abad ke-21 }\end{array}$ & $\begin{array}{c}\text { Daftar Kompetensi Abad } \\
\text { ke-21 }\end{array}$ & Karakter Terkait \\
\hline \multicolumn{3}{|l|}{ Kompetensi Kognitif } \\
\hline \multirow[t]{8}{*}{ Strategi dan Proses Kognitif } & Berpikir Kritis & $\begin{array}{l}\text { Penilaian } \\
\text { (Judgment) }\end{array}$ \\
\hline & Penyelesaian masalah & Perspektif \\
\hline & Penalaran/Argumentasi & \\
\hline & Analisis & Perspektif \\
\hline & Interpretasi & Penilaian \\
\hline & Fungsi Eksekutif & \\
\hline & Membuat Keputusan & $\begin{array}{l}\text { Penilaian } \\
\text { (Judgment) }\end{array}$ \\
\hline & Pembelajaran Adaptif & \\
\hline \multirow[t]{2}{*}{ Pengetahuan } & Literasi Informasi & Gemar Belajar \\
\hline & $\begin{array}{l}\text { Literasi Informasi \& } \\
\text { Teknologi Komunikasi } \\
\text { Mendengar aktif } \\
\text { Komunikasi Lisan E Tertulis }\end{array}$ & \\
\hline \multirow[t]{2}{*}{ Kreativitas } & Kreativitas & Kreativitas \\
\hline & Inovasi & \\
\hline \multicolumn{3}{|l|}{ Kompetensi Intrapersonal } \\
\hline \multirow[t]{9}{*}{ Keterbukaan Intelektual } & Fleksibilitas & Kreativitas \\
\hline & Apresiasi seni dan budaya & $\begin{array}{l}\text { Apresiasi } \\
\text { keindahan \& } \\
\text { kesempurnaan }\end{array}$ \\
\hline & $\begin{array}{l}\text { Tanggung jawab pribadi } \\
\text { dan sosial (termasuk }\end{array}$ & $\begin{array}{l}\text { Kewarganegraan/ } \\
\text { kerjasama }\end{array}$ \\
\hline & $\begin{array}{l}\text { kesadaran dan kompetensi } \\
\text { budaya) }\end{array}$ & Kecerdasan sosial \\
\hline & Apresiasi perbedaan & Perspektif \\
\hline & Pembelajaran berkelanjutan & Gemar belajar \\
\hline & Ketertarikan dan & Rasa ingin tahu \\
\hline & keingintahuan intelektual & \\
\hline & Kemampuan beradaptasi & \\
\hline \multirow[t]{7}{*}{ Etos Kerja/Hati Nurani } & Ketekunan & Ketekunan/ketaba \\
\hline & Ketabahan hati & han \\
\hline & Tanggung jawab & Integritas \\
\hline & Integritas & Integritas \\
\hline & Inisiatif & Keberanian \\
\hline & Kemandirian & \\
\hline & $\begin{array}{l}\text { Regulasi diri- jenis 1: } \\
\text { ketrampilan metakognitif, }\end{array}$ & $\begin{array}{l}\text { Regulasi diri }+ \\
\text { perspektif }\end{array}$ \\
\hline
\end{tabular}




\begin{tabular}{|c|c|c|}
\hline $\begin{array}{c}\text { Kelompok Kompetensi } \\
\text { Abad ke-21 }\end{array}$ & $\begin{array}{l}\text { Daftar Kompetensi Abad } \\
\text { ke-21 }\end{array}$ & Karakter Terkait \\
\hline Evaluasi diri positif & $\begin{array}{l}\text { termasuk pemikiran, } \\
\text { kinerja, refleksi pribadi } \\
\text { Regulasi diri- jenis 2: } \\
\text { pemantauan diri, evaluasi } \\
\text { diri, penguatan diri } \\
\text { Kesehatan fisik \& psikis }\end{array}$ & $\begin{array}{l}\text { Regulasi diri + } \\
\text { harapan }\end{array}$ \\
\hline $\begin{array}{l}\text { Kompetensi interpresonal } \\
\text { Kerjasama tim \& kolaborasi }\end{array}$ & Komunikasi & $\begin{array}{l}\text { Kewarganegaraan } \\
\text { / kerjasama }\end{array}$ \\
\hline Kepemimpinan & $\begin{array}{l}\text { Kolaborasi } \\
\text { Kerjasama Tim } \\
\text { Kerjasama } \\
\text { Kordinasi } \\
\text { Ketrampilan interpersonal } \\
\text { Rasa percaya } \\
\text { Resolusi konflik } \\
\text { Negosias } \\
\text { Empati/adopsi sudut } \\
\text { pandang } \\
\text { Orientasi layanan } \\
\text { Kepemimpinan } \\
\text { Komunikasi asertif } \\
\text { Presentasi diri } \\
\text { Pengaruh sosial terhadap } \\
\text { orang lain }\end{array}$ & $\begin{array}{l}\text { Kasih sayang + } \\
\text { perspektif } \\
\text { Kebaikan } \\
\text { Kepemimpinan } \\
\text { Keberanian }\end{array}$ \\
\hline
\end{tabular}

Tabel 1 menunjukkan hubungan antara kompetensi abad 21 dengan kekuatan karakter (kolom 2 dan kolom 3). Contohnya, berpikir kritis dihubungan dengan aspek penilaian (yaitu memikirkan dan memeriksa hal-hal tertentu dari segala sisi; membuat kesimpulan dengan hati-hati; mampu mengubah pemikiran seseorang lewat bukti-bukti nyata). Dapat dikatakan bahwa, penilaian (judgment) mendukung perkembangan ketrampilan berpikir kritis. Beberapa kompetensi didasarkan pada lebih dari satu kekuatan karakter. Contohnya, analisis dan interpretasi dari argumen yang berbeda tidak hanya bergantung pada perspektif (cara melihat dunia dari sudut pandang pribadi dan sudut pandang orang lain) tetapi juga dipengaruhi oleh elemen judgment (penilaian). Perlu dicatat bahwa setidaknya perkembangan kompetensi-kompetensi tertentu dipengaruhi oleh kemampuan intelektual atau kemampuan sosial seseorang yang melampaui karakter/sifat-sifatnya.

Secara garis besar, hubungan antara kekuatan karakter dan kompetensi abad 21, termasuk definisi teoritisnya, menyiratkan bahwa kekuatan karakter merupakan fondasi psikologis yang mendukung pemerolehan dan perkembangan kompetensi-kompetensi abad ke-21. Contohnya, "rasa ingin tahu" dapat mendukung perkembangan minat intelektual, "gemar belajar" dapat mendukung 
perkembangan literasi informasi dan komunikasi serta pembelajaran berkelanjutan, dan "rasa sayang" dapat mendukung perkembangan empati. Oleh karena itu, kekuatan karakter dapat dianggap sebagai dasar pembangunan kompetensi abad ke-21 (Gambar 2).

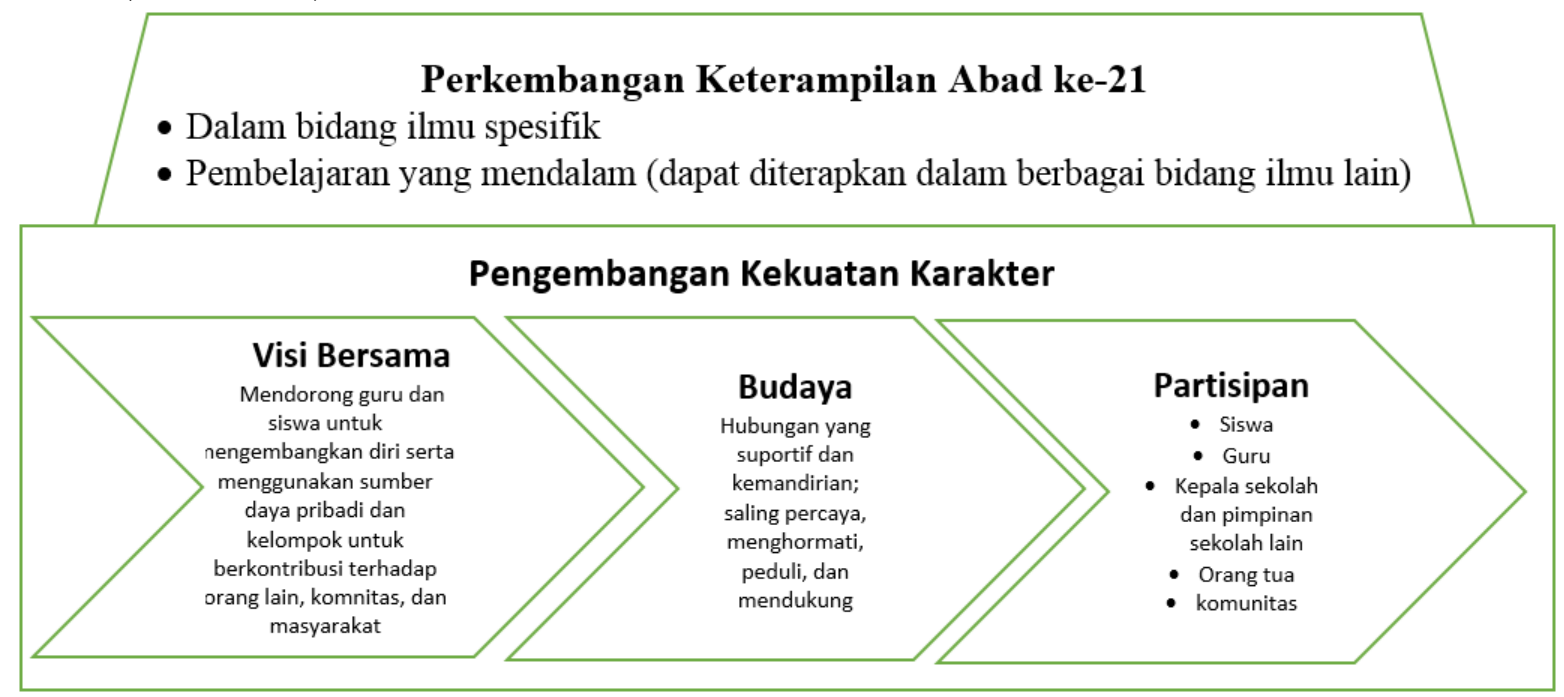

Gambar 2. Contoh Dasar Pembangunan Kekuatan Karakter dan Kompetensi Abad ke-21 Berkelanjutan

Gambar 2 mengilustrasikan bahwa kekuatan karakter guru dan siswa dapat membantu mengembangkan keterampilan abad ke-21. Proses eksplorasi cara-cara baru untuk menggunakan kekuatan karakter tersebut dapat difasilitasi dengan menciptakan budaya peduli berdasarkan tingkat kepercayaan, respek, dan otonomi yang sama antara guru dan siswa, sehingga visi sekolah dapat tercapai. Proses perkembangan karakter dapat didukung dengan cara melibatkan lebih banyak orang (misalnya, melibatkan orang tua) dan memberikan kesempatan bagi individu untuk mendiskusikan dan mengaplikasikan kekuatan karakter serta potensi mereka. Sekolah dapat mengambil langkah awal dan menformulasi kebijakan serta prosedur yang dapat mendukung perkembangan karakter, salah satunya dengan merancang proses evaluasi yang berpusat pada pembelajaran. Sekolah juga dapat membuat kebijakan-kebijakan terkait pelatihan sumber daya manusia dan pengembangan diri di dalam atau di luar jam sekolah.

\section{Pendidikan Karakter}

Pendidikan karakter sering juga disebut dengan pendidikan nilai karena karakter adalah value in action nilai yang diwujudkan dalam tindakan. Karakter juga sering disebut operative value atau nilai-nilai yang dioperasionalkan dalam tindakan (perilaku). Oleh karena itu, pendidikan karakter pada dasarnya merupakan upaya dalam proses menginternalisasikan, menghadirkan, menyemaikan, dan mengembangkan nilai-nilai kebaikan pada diri siswa. Dengan internalisasi nilainilai kebajikan pada diri siswa, diharapkan dapat mewujudkan perilaku baik (Akbar, 2011). Berikut ini adalah prinsip dasar pendidikan karakter.

1. Karakter dapat dididik dan kemajuannya dapat dinilai secara holistik

2. Karakter adalah hal penting, karakter berkontribusi pada kemajuan seseorang dan masyarakat 
3. Pendidikan yang baik adalah pendidikan karakter yang baik

4. Karakter sebagian besar diperoleh melalui pemodelan peran dan pengaruh emosional: budaya dan etos sekolah adalah hal yang penting

5. Budaya sekolah memungkinkan siswa memeroleh karakter yang baik

6. Karakter juga harus diajarkan: pembelajaran karakter secara langsung akan memberikan dasar pemikiran dan sarana untuk mengembangkan karakter di dalam dan di luar sekolah

7. Karakter harus dikembangkan bersama dengan orang tua, organisasi masyarakat, dan pemerintah

8. Pendidikan karakter adalah tentang keadilan dan setiap anak berhak untuk memperoleh pengembangan karakter

9. Pengembangan karakter positif akan memberdayakan siswa

10. Karakter yang baik menunjukkan kesiapan untuk belajar dari orang lain

11. Karakter yang baik mengembangkan kewarganegaraan yang demokratis dan pengambilan keputusan yang otonom

Pendidikan karakter mengajarkan akuisisi (pemerolehan) dan penguatan kebajikan yaitu sifat-sifat yang menopang kehidupan dalam masyarakat. Kemampuan siswa dalam pengetahuan dan keterampilan menjadi prediktor penting dalam pencapaian keberhasilan siswa. Komponen paling penting yang dibutuhkan untuk berbagai macam profesi adalah kualitas karakter sehingga hal ini perlu dibelajarkan di sekolah. Tujuannya adalah:

1. membangun fondasi untuk pembelajaran seumur hidup;

2. mendukung hubungan yang berhasil di rumah, di masyarakat, dan di tempat kerja;

3. mengembangkan nilai-nilai pribadi dan kebajikan untuk partisipasi berkelanjutan dalam dunia yang terglobalisasi;

4. mengembangkan akal sehat, atau kebijaksanaan praktis dan kapasitas untuk memilih secara cerdas di antara berbagai alternatif. Kapasitas ini melibatkan pengetahuan bagaimana memilih tindakan yang tepat dalam situasi yang sulit dan secara bertahap muncul dari pengalaman membuat pilihan dan pertumbuhan wawasan etis.

Pendidikan karakter lebih dari sekedar subjek karena memiliki tempat dalam budaya dan fungsi keluarga, ruang kelas, sekolah dan lembaga lainnya. Pendidikan karakter adalah tentang membantu siswa memahami apa yang secara etis penting dalam situasi dan bagaimana bertindak untuk alasan yang benar, sehingga mereka menjadi lebih mandiri dan efektif. Karakter dan kebajikan bukanlah gagasan agama semata. Karakter dan kebajikan juga bukan konsep paternalistik.

Walters (2012) merangkum beberapa pengertian pendidikan karakter sebagai berikut. Pendidikan karakter adalah tentang mengembangkan kebajikan moral (kejujuran, kasih sayang, empati, dan kepercayaan) dan kebajikan kinerja (usaha, ketekunan, dan kegigihan). Pendidikan karakter bukan hal baru, namun sudah setua seperti pendidikan itu sendiri. Pendidikan karakter adalah pendekatan apa pun yang disengaja di mana semua pihak sekolah, bersama dengan orang tua dan anggota masyarakat, membantu anak-anak menjadi sosok yang penuh 
perhatian, berprinsip, dan bertanggung jawab. Sepanjang sejarah, di negara-negara di seluruh dunia, pendidikan memiliki dua tujuan besar: untuk membantu seseorang menjadi baik dan bijak.

Perkembangan karakter dan bagaimana untuk meningkatkannya melalui pendidikan dapat digambarkan dengan teori perkembangan moral NeoAristotelian Model (Gambar 3). Teori ini mengedepankan pentingnya pengasuhan keluarga awal, meskipun tidak mengecualikan penyesuaian sifat-sifat moral negatif yang terbentuk pada anak usia dini. Bermula pada awal pendidikan karakter yang diterima seseorang, mereka kemudian dapat mengembangkan karakternya dengan baik melalui lintasan kebajikan yang dilakukan melalui pembiasaan, atau seseorang dapat mengembangkan karakter secara mandiri dan reflektif, yang pada gilirannya memberi mereka motivasi intrinsik untuk melakukan tindakan kebajikan. Seseorang mungkin juga mengalami "jalan memutar" untuk menuju jalur kebajikan, yang adakalanya "dilemahkan" oleh dirinya sendiri. Kemudian, melalui pembiasaan oleh "peraturan", mereka akan termotivasi secara ekstrinsik untuk bertindak menuju kebajikan.

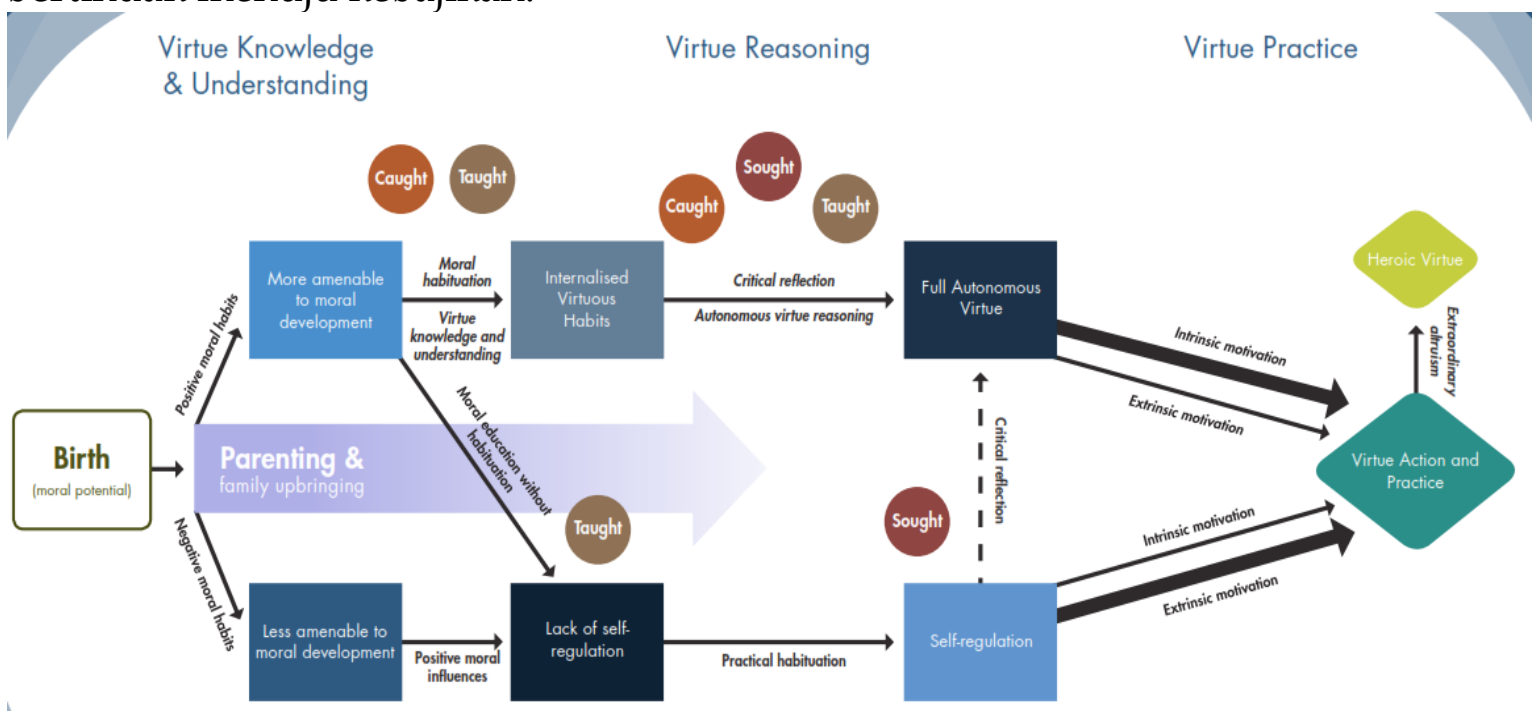

Gambar 3. Teori Perkembangan Moral menurut Neo-Aristotelian Model

Beberapa penjelasan istilah dalam Gambar 2. Caught: komunitas sekolah baik staf dan guru memberikan contoh, budaya, inspirasi, dan etos positif yang memotivasi dan mendukung pengembangan karakter. Taught: sekolah menyediakan pengalaman pendidikan di dalam dan di luar kelas yang membekali siswa dengan bahasa, pengetahuan, pemahaman, keterampilan dan atribut yang memungkinkan pengembangan karakter. Sought: sekolah menyediakan beragam kesempatan yang memicu pembentukan kebiasaan pribadi dan komitmen karakter. Hal-hal tersebut akan membantu siswa dari waktu ke waktu untuk mencari dan bergairah untuk mengembangkan karakternya sendiri secara bebas.

Pelajaran penting yang dapat diambil dari teori ini bahwa pendidik karakter tidak boleh 'menyerah' dengan harapan bahwa seorang siswa dapat dibantu dalam perjalanan menuju kebajikan. Tidak ada dua orang yang akan maju menuju kebajikan dengan cara yang persis sama, juga tidak pada kecepatan yang sama persis. Semua ketentuan dalam bidang pendidikan karakter perlu 
mempertimbangkan perbedaan kontekstual dan individual dan mencari solusi praktis untuk masing-masing sekolah, kelas, atau siswa. Karakter dan integritas guru lebih penting untuk menjadi teladan di kelas, bahkan lebih penting daripada penguasaan konten dan teknik mengajar.

Dalam budaya manapun, tujuan utama pendidikan adalah membesarkan anak-anak dengan karakter yang baik (Brown dkk. 2012). Seperti yang disampaikan oleh Park dan Peterson (2009), "karakter yang baik adalah hal yang akan selalu dicari dalam setiap hubungan orang tua-anak, guru-siswa, antar saudara, dan teman sejawat". Aspek-aspek dari karakter yang baik, yang bernilai moral tinggi, dianggap sebagai komponen-komponen inti dari perkembangan generasi muda yang optimal, yang melampaui ketrampilan, kemampuan, dan pengetahuan yang biasanya diajarkan di sekolah-sekolah pada umumnya. Individu-individu yang berkarakter buruk tidak memiliki motivasi, keberanian, ketekunan, ataupun keinginan untuk melakukan hal yang benar secara moral atau sosial.

Beberapa dekade terakhir, sekolah-sekolah telah menjalankan programprogram pendidikan karakter, yang beberapa diantaranya berdampak pada menurunnya jumlah perilaku berbahaya. Selain itu, pendidikan karakter juga dapat meningkatkan kompetensi prososial, perilaku-perilaku positif, hasil belajar, dan fungsi sosial-emosional. Program-program tersebut pada umumnya bertujuan untuk "mendukung perkembangan intelektual, sosial, emosional, dan etika generasi muda dan mengajari mereka tentang komitmen, tanggung jawab, kepedulian, dan kontribusi sebagai warga negara" (Lickona, dkk. 2007; Pala, 2011).

\section{Perspektif Pengembangan Karakter: Siswa, Guru, Sekolah}

Pengembangan karakter dapat dilakukan melalui intervensi pada tingkat: 1) siswa 2) guru (dan siswa); dan 3) sekolah (termasuk guru dan siswa). Berikut ini penjelasan ringkasnya.

\section{Tingkat Siswa}

Intervensi pada tingkat siswa mencakup seperangkat sesi pertemuan yang dilengkapi dengan kegiatan follow-up, yang dapat dilakukan oleh pelatih eksternal atau oleh guru kelas dengan mengadopsi materi dan/atau panduan dari sumber eksternal. Sesi-sesi tersebut dapat dimulai dengan mengenali karakter seseorang (dengan mengisi angket, lewat dialog atau diskusi), dan kemudian pemberian gambaran karakter tertentu, latihan-latihan - misal menulis sebuah cerita tentang kelebihan yang dimiliki, dan sebuah latihan follow-up (misal mencoba mengaplikasikan karakter tersebut di sekolah atau dalam hobi atau mata pelajaran) (Quinlan dkk. 2015). Hampir semua program intervensi melatih para peserta untuk memanfaatkan kekuatan karakternya dengan cara yang baru, dan mengaplikasikan karakter tersebut dalam menyelesaikan permasalahan sehari-hari, membangun hubungan, ataupun menganalisis teks, film, sikap atau perilaku diri sendiri atau seseorang yang dijumpai di sekolah (Oppenheimer dkk. 2014).

Seperti yang telah dijelaskan di atas, beberapa dari program yang berpusat pada siswa tersebut, menunjukkan efek positif pada proses pembelajaran, prestasi akademik (Ledertoug 2016), sikap (Quinlan dkk 2015), kepuasan hidup (Proctor dkk 2011), pemanfaatan kekuatan karakter, kekompakan kelas (Quinlan dkk 2015), dan ketrampilan sosial para siswa (Rashid dkk. 2013). Program tersebut akan lebih 
berdampak signifikan ketika dilaksanakan oleh guru kelas dengan menyesuaikan iklim kelas (Ledertoug 2016). Hasil-hasil penelitian menunjukkan bahwa intervensi yang dilakukan oleh guru kelas lebih efektif daripada yang dilakukan oleh pelatih eksternal yang profesional (Waters dkk 2015). Program-program intervensi pengembangan karakter seperti ini terdiri dari diskusi, kegiatan yang melibatkan siswa, dan latihan-latihan yang dapat dikerjakan oleh para siswa (Ghielen dkk 2017).

2. Tingkat Guru

Jenis intervensi kedua adalah yang berpusat pada guru. Program ini dilakukan berdasarkan anggapan bahwa kepribadian, motivasi, perspektif moral, dan pola pikir psikologis guru dapat mempengaruhi proses pembelajaran dan kapasitas proses tersebut untuk membentuk pola pikir serta perilaku siswa (Noddings 2015). Terdapat istilah "kita mengajarkan siapa kita" dan oleh sebab itu mendorong perkembangan karakter dalam pendidikan merupakan awal dari pekerjaan internal seorang guru. Pengakuan akan kualitas guru akan dapat memajukan pembelajaran dan meningkatkan motivasi serta prestasi siswa.

Data empiris membuktikan bahwa ketika seseorang bekerja dengan kelebihan-kelebihan yang dimilikinya, ia akan lebih termotivasi, lebih menikmati pekerjaan tersebut, dan memiliki performa yang lebih bagus. Program-program intervensi pada tingkat guru dimulai dengan sebuah proses untuk meningkatkan kelebihan/karakter guru; membantu guru memahaminya dengan baik (misal dengan mendiskusikannya), memotivasi guru untuk menggunakan kelebihankelebihan tersebut (misal lewat diskusi atau latihan-latihan), dan membantu guru mengadopsi pola pikir berkarakter (Ho dkk, 2017; Lottman dkk, 2017).

Bantuan pedagogis untuk mendorong para guru menyampaikan materi kepada siswa dapat diberikan pada tahap kedua. Jenis intervensi ini akan lebih lama bertahan karena guru memiliki motivasi dan kemampuan untuk menjadi contoh dalam proses pengembangan karakter. Namun, dibutuhkan lebih banyak data empiris untuk mendukung pernyataan tersebut.

3. Tingkat Sekolah

Jenis intervensi ketiga adalah yang dilakukan pada tingkat sekolah. Program-program intervensi pada tingkat sekolah jarang ditemukan pada jurnaljurnal ilmiah ( $\mathrm{O}^{\prime}$ Connor dan Cameron 2017). Kebanyakan dari program-program berbasis sekolah tersebut tidak hanya dipusatkan pada pengembangan karakter, namun mengadopsi kerangka psikologis positif yang lebih umum. Intervensi pada tingkat sekolah memiliki karakteristik yang berbeda, terdiri dari sebuah program yang telah disusun sedemikian rupa yang melibatkan beberapa intervensi yang berbeda (misal, bagi anggota staf, atau kelas-kelas serta mata pelajaran tertentu). Program terintegrasi ini dianggap dapat menghasilkan dampak yang lebih kentara, karena para siswa dan guru menerima program yang sama tentang pengembangan karakter dan bagaimana cara mengaplikasikannya sehingga pola pikir berkarakter dapat dicapai.

Secara empiris, telah terbukti bahwa dukungan organisasi terhadap aplikasi kekuatan karakter sering dikaitkan dengan peningkatan kinerja guru Program intervensi pada tingkat sekolah berdasar kepada visi dan tujuan sekolah. Visi ini merupakan dasar dari sebuah budaya organisasi yang memampukan, mendukung, 
dan memotivasi adanya program pengembangan karakter. Literatur-literatur terdahulu yang membahas tentang organisasi pendidikan menekankan pentingnya menyesuaikan perubahan yang ada dengan proses, rutinitas, struktur, dan budaya sekolah sehari-hari. Kepemimpinan sekolah ditandai indikator utama perubahan dan keberlanjutan organisasi. Artinya, kepemimpinan sekolah membantu memelihara perubahan dengan menciptakan iklim dan struktur organisasi yang mendukung dan dengan merencanakan prioritas yang sejalan dengan tujuan perubahan. Hasil dari proses seperti ini adalah institusionalisasi perubahan yang sistematis dalam perilaku, ekspektasi, mekanisme dukungan, dan struktur organisasi pendidikan itu sendiri.

Penelitian membuktikan bahwa praktik-praktik dan intervensi pada tingkat organisasi dapat mempengaruhi praktik-praktik pada bidang lain. Contohnya, guru yang memberikan intervensi pengembangan karakter pada siswa dapat pula mengaplikasikan intervensi tersebut pada aspek lain dalam pekerjaan mereka (misalnya dengan kolega di sekolah). Pada tingkatan-tingkatan yang lebih tinggi, dampak aplikasi karakter tersebut dapat menjadi lebih besar karena akan mempengaruhi lebih banyak orang. Di samping itu, praktik-praktik pada tingkatan yang lebih tinggi juga dapat mempengaruhi kultur/budaya organisasi (seperti kerangka pengembangan karakter di sekolah). Menggabungkan tindakan pada ketiga tingkatan tersebut (sekolah, guru, dan siswa) dapat menghasilkan sebuah kerangka pengembangan karakter yang terintegrasi, efektif, dan berkelanjutan sehingga kekuatan karakter dapat ditingkatan.

\section{Sekolah sebagai Wahana Pendidikan Karakter}

Pengembangan karakter anak-anak adalah kewajiban kita semua, tidak terkecuali orang tua. Orang tua adalah pendidik utama dari karakter anak-anak mereka, namun demikian, para orang tua ingin bahwa semua orang dewasa yang memiliki hubungan dengan anak-anak mereka untuk berkontribusi pada pendidikan karakter tersebut, terutama guru anak-anak mereka.

Meningkatnya beban kerja dan keuangan orang tua, menyebabkan waktu yang lebih lebih sedikit untuk dapat mendampingi anak-anaknya. Berbagai kemajuan teknologi juga bersaing merebut perhatian dan waktu anak-anak untuk bersama orangtua mereka. Sekolah memiliki peran penting dalam pendidikan karakter. Pendidikan karakter merupakan program yang harus disengaja dirancang di sekolah, untuk mengembangkan individu yang berkarakter baik. Mengingat jumlah waktu yang dihabiskan seorang anak di sekolah cukup banyak, sehingga sekolah merupakan lingkungan yang ideal untuk menanamkan nilainilai karakter. Sekolah merupakan tempat pembelajaran yang penting untuk memupuk tanggung jawab etis dan sosial dalam diri seseorang, peduli pada orang lain, kejujuran, kebaikan dan kasih sayang, tanggung jawab, dan sifat-sifat penting lainnya.

Karakter yang baik tidak terbentuk secara otomatis, namun harus dikembangkan dari waktu ke waktu melalui proses pembelajaran, teladan, dan praktik yang berkelanjutan melalui pendidikan karakter. Pembelajaran karakter yang disengaja sangat penting dalam masyarakat saat ini karena remaja kita menghadapi banyak peluang dan bahaya yang tidak dialami oleh generasi 
sebelumnya. Mereka dibombardir dengan lebih banyak pengaruh negatif melalui media dan sumber-sumber eksternal lain dalam budaya saat ini (Pala, 2011). Ratusan jam per tahun adalah waktu yang dihabiskan anak-anak di sekolah, oleh karena itu penting agar sekolah membantu keluarga dan masyarakat dengan mengembangkan lingkungan yang penuh perhatian dan saling menghormati di mana siswa belajar nilai-nilai karakter.

Semua pihak di sekolah adalah pendidik karakter, baik guru, tenaga kependidikan, penjaga sekolah, tenaga kebersihan sekolah, penjaga kantin sekolah, sopir kendaraan sekolah, atau tenaga lainnya. Semua pihak ikut andil dalam membentuk karakter anak-anak yang berhubungan dengan pihak tersebut, mulai dari cara berbicara, perilaku yang ditampilkan, perilaku toleransi, dan segala hal yang dilakukan merupakan bagian dari pendidikan karakter yang diberikan kepada anak-anak. Pertanyaannya, apakah semua pihak telah melakukannya dengan baik? Apakah pendidikan karakter di sekolah telah dirancang secara sengaja dan terencana, atau hanya secara kebetulan? Apa sajakah nilai-nilai yang telah kita ajarkan di sekolah? Secara sederhana, pendidikan karakter adalah segala yang kita lakukan yang memengaruhi karakter anak-anak yang kita ajar. Pendidikan karakter adalah upaya yang disengaja untuk membantu orang memahami, peduli, dan bertindak berdasarkan nilai-nilai etika yang mendasar.

Pendidikan karakter di sekolah akan lebih efektif apabila diintegrasikan ke dalam setiap matapelajaran dan dilakukan secara rutin, misalnya matapelajaran IPA, pendidikan jasmani, matematika, seni bahasa, dan lain-lain. Jika seorang anak kemudian diberi banyak kesempatan memperoleh pengalaman untuk melatih nilainilai karakter melalui interaksi tatap muka atau interaksi langsung, hal ini kemudian akan ditransmisikan ke komunitas atau lingkungan yang lebih luas.

Kegiatan-kegiatan pedagogis di luar pembelajaran, seperti bermain, penyelidikan, debat, desain, kinerja, dan olahraga dapat menjadi pilihan dalam membelajarkan karakter. Kegiatan-kegiatan ini dapat menampilkan karakteristik berikut.

1. Pertumbuhan pola pikir

2. Perkembangan moral

3. Kesadaran

4. Kompetisi dan kolaborasi

5. Proses, bukan hanya pengetahuan biasa

6. Metakognitif sistematis (refleksi atas proses)

7. Kebijaksanaan, sensitivitas

Pembentukan karakter akan berhasil ketika sekolah mengambil peran secara langsung. Langkah berikut dapat dilakukan.

1. Setiap sekolah perlu menggambarkan jenis-jenis karakter yang akan dikembangkan dan kemudian menguraikan filosofi yang mendasari pendekatannya dalam pengembangan siswa-siswanya.

2. Sekolah memberikan kesempatan kepada siswa untuk tidak hanya berpikir dan melakukan, tetapi juga memahami apa artinya menjadi orang yang dewasa dan efektif. 
3. Komunitas sekolah baik staf dan siswa memberikan contoh, budaya, dan pengaruh inspirasional dalam etos positif yang memotivasi dan meningkatkan pengembangan karakter.

4. Sekolah memberikan pengalaman pendidikan di dalam dan di luar kelas yang membekali siswa dengan bahasa, pengetahuan, pemahaman, keterampilan dan atribut yang memungkinkan pengembangan karakter.

5. Sekolah menyediakan beragam peluang yang menghasilkan pembentukan kebiasaan pribadi dan komitmen karakter. Ini membantu siswa dari waktu ke waktu untuk mencari, menginginkan, dan secara bebas mengejar pengembangan karakter mereka.

Menurut Burret dan Rusnak (1993) pendidikan karakter harus terintegrasi, melibatkan peran keluarga, lingkungan atau komunitas, sekolah dan kebijakan administratif. Terdapat enam prinsip untuk implementasi pendidikan karakter terintegrasi.

1. Pendidikan karakter menjadi bagian setiap subyek atau matapelajaran, bukan menjadi pelajaran tersendiri.

2. Sekolah dan komunitas menjadi bagian yang sangat penting dalam pendidikan karakter.

3. Lingkungan kelas yang positif akan mendukung pendidikan karakter.

4. Guru yang memiliki "power" sangat berperan pada terwujudnya tujuan pendidikan karakter.

5. Pendidikan karakter harus didukung oleh kebijakan administratif dan praktis.

6. Pendidikan karakter adalah pendidikan tindakan (bukan sekedar teori).

Pengembangan karakter adalah proses yang membutuhkan upaya dari individu yang berkembang dan masyarakat serta sekolah. Masyarakat yang memiliki tekad untuk memungkinkan anggotanya hidup dengan baik akan memperlakukan pendidikan karakter sebagai sesuatu yang penting. Sekolah hendaknya merancang jenis apa yang akan dikembangkan, dan bagaimana menyeimbangkan berbagai kebajikan dan nilai-nilai dalam proses ini. Sekolah harus membantu siswa dalam belajar mengenal yang baik, mencintai yang baik, dan melakukan hal yang baik. Sekolah memungkinkan siswa untuk menjadi orang dan warga negara yang baik, mampu menjalani kehidupan yang baik, serta menjadi orang yang sukses. Oleh karena itu sekolah berperan penting dalam pembentukan karakter.

Terdapat tiga upaya yang bisa dilakukan pihak yang terlibat dalam pembentukan karakter. Pertama, adalah mengembangkan pengetahuan dan pemahaman istilah-istilah kebajikan. Kedua, adalah mengembangkan kemampuan dan kemauan untuk menerapkan kebajikan pada konteks kehidupan nyata. Ketiga, adalah memperkuat karakter di berbagai tempat dan situasi seperti di ruang kelas, tempat bermain, interaksi antara guru dan siswa, dalam pertemuan, poster, komunikasi, pelatihan staf, dan dalam hubungan dengan orang tua.

Beberapa pakar menyarankan pola pembelajaran karakter, diantaranya Thomas Lickona dengan 7E berikut.

1. Explain it - jelaskan, tetapkan, gambarkan, dan diskusikan pentingnya nilai karakter. 
2. Examine it - pelajari dan perhatikan dari berbagai pustaka, sejarah, dan peristiwa terkini terkait karakter.

3. Exhibit it - tunjukkan melalui contoh-contoh pribadi.

4. Expect it - harapkan karakter tersebut dimiliki melalui aturan, janji, dan konsekuensi.

5. Experience it - berikan pengalaman langsung.

6. Encourage it - dorong pengembangan karakter melalui penetapan tujuan, latihan dan penilaian diri.

7. Evaluate it - evaluasilah, berikan umpan balik.

Pendidikan karakter diharapkan dapat membantu anak-anak mengoptimalkan pertumbuhan sosial dan emosional mereka, membangun ketahanan diri, mengembangkan penalaran moral, membangun keterampilan berpikir etis dan kritis, kemampuan mengatasi masalah dan kemampuan mediasi. Berbagai keterampilan tersebut akan sangat berguna di sepanjang hidupnya untuk mengatasi berbagai masalah dan kesulitan, tidak mementingkan diri sendiri, bermartabat, dan senantiasa penuh keberanian menghadapi tantangan.

Berbagai penelitian menemukan bahwa pendidikan karakter juga secara signifikan membantu siswa dalam kemampuan akademik, dengan menanamkan ketekunan dan tanggung jawab yang memungkinkan mereka untuk fokus dan tetap termotivasi dalam belajar mereka. Bukti juga menunjukkan hanya ada sedikit kejadian membolos dan teguran ketidakdisiplinan, kehadiran yang lebih tinggi, harga diri dan kinerja akademik yang lebih baik ketika pendidikan karakter diintegrasikan ke dalam kurikulum sekolah. Pendidikan karakter juga memungkinkan anak-anak berinteraksi dengan baik dengan guru dan teman sebaya mereka, lebih produktif dan tertarik dalam belajar. Ketika anak-anak tumbuh kelak, hal ini diharapkan menjadi dasar dalam berinteraksi yang baik dengan orang lain di lingkungannya.

\section{KESIMPULAN}

Pengembangan karakter anak-anak tidak bisa dianggap enteng karena hal ini akan menjadi penentu jenis komunitas dan masyarakat yang akan kita miliki di masa depan. Pendidikan karakter merupakan sarana yang sangat diperlukan bagi mereka untuk menghadapi peluang, tekanan, dan tantangan abad ke-21 dengan cara yang memungkinkan mereka untuk berkembang dan menjadi sukses.

Kekuatan karakter merupakan dasar dari pembangunan kerangka dan perspektif yang positif serta relevan, yang bermanfaat untuk meningkatkan fungsi dan kesejahteraan individu, kelompok, dan institusi. Implementasi dan usaha memajukan kekuatan karakter lewat lembaga-lembaga pendidikan yang mencetak warga negara dan para pemimpin masa depan menghadapi banyak tantangan unik. Dalam hal ini, pendidikan tidak hanya menjadi salah satu bidang dimana kekuatan karakter dapat diasah. Akan tetapi, jika memang tujuan utama kita adalah menyediakan pendidikan yang bermanfaat bagi generasi muda, pendidikan merupakan suatu sektor yang mewajibkan adanya pengembangan dan penerapan kekuatan karakter. Pendidikan yang bermanfaat tersebut dapat membantu para generasi muda untuk terus berkembang serta dapat memberikan kontribusi bagi 
masyarakat di sekitar mereka, khususnya dalam dunia abad ke-21 satu ini yang berubah-ubah dengan sangat cepat.

\section{SARAN}

Perlu digarisbawahi bahwa pendidikan karakter bukan berarti mengurangi atau menggantikan tujuan pendidikan "tradisional" seperti akumulasi pengetahuan dan pengembangan kemampuan intelektual dan praktis. Pendidikan karater yang dijalankan dengan baik, tidak hanya akan berdampak pada well being dan karakter yang baik namun juga pada hasil belajar yang baik.

Pendidikan karakter merupakan proses yang panjang dan berkelanjutan yang melibatkan banyak orang, dimulai dari rumah bersama keluarga. Peran orang tua dan anggota keluarga lainnya dalam membentuk kepercayaan, moral, dan perilaku anak tidak dapat dianggap remeh. Jika pendidikan karakter tersebut diintegrasikan ke dalam kurikulum sekolah, maka pengembangan karakter akan lebih diperkuat.

\section{DAFTAR PUSTAKA}

Akbar, S. (2011). Revitalisasi Pendidikan Karakter di Sekolah Dasar. Pidato Pengukuhan Guru Besar sebagai Guru Besar dalam Bidang Ilmu Pendidikan Dasar 7 pada Fakultas Ilmu Pendidikan (FIP) UM, Kamis, 8 Juni 2011.

Banicki, K. (2017). The character-personality distinction: An historical, conceptual, and functional investigation. Theory $\mathcal{E}$ Psychology , 27(1): 50 -68.

Bialik, M., Bogan , M., Fadel , C., \& Horvathova , M. (2015). Character Education for the 21st Century: What Should Students Learn? Boston, Massachusetts: Center for Curriculum Redesign.

Brown, P., Corrigan, M. W., \& Higgins-D'Alessandro, A. (Eds.). (2012). Handbook of Pro-social Education (Vol. 1). Rowman \& Littlefield.

Burret, K., \& Rusnak, T. (1993). Integrated Character Education. Bloomington: Phi Delta KappaEducational Foundation.

Colgan, C. (2003). Making Character Education Work. American School Board Journal, 190(11), 34-35.

Education, D. F. O. R., Committee, E. P., \& Committee, E. P. (2018). Future of Education and Skills 2030: Conceptual Learning Framework. Organization for Economic Co-operation and Development.

Elias, M. J. (2014). The Future of Character Education and Social-Emotional Learning: The Need for Whole School and Community-Linked Approaches. Journal of Character Education, 10(1): 37-42.

Fink, K., and Geller, K. (2013). Integrating Common Core and Character Education: Why it is Essential and How it Can Be Done. Character Education Partnership.

Fitz Simons, E. M. (2013). Character education: A role for literature in cultivating character strengths.

Ghielen, S. T. S., van Woerkom, M., \& Christina Meyers, M. (2017). Promoting positive outcomes through strengths interventions: A literature review. The Journal of Positive Psychology,1-13.

Ho, S. M., Mak, C. W., Ching, R., \& Lo, E. T. (2017). An approach to motivation and empowerment: The application of positive psychology. In I. H. Amzat \& N. P. Valdez (Eds.), Teacher Empowerment toward Professional Development and Practices (pp. 167-182). Singapore: Springer. 
Hoerle, H. (tanpa tahun). Character Assessment and Education in the 21st Century. SSATB.

Hoerle, H. (tanpa tahun). Character Assessment in the 21st Century. The Enrollment Management Association.

Johnson, J. A. (1999). Moral Education for the 21st Century: A Survey of Japanese and Chinese teachers.

Jolls, T. (2008). The impact of technology on character education. USA [United States of America]: Center for Media Literacy.

Lapsley, D. K., \& Narvaez, D. (2006). Character education. Handbook of child psychology. 248-295.

Lavy, S. (2019). A Review of Character Strengths Interventions in Twenty-FirstCentury Schools: their Importance and How they can be Fostered. Applied Research in Quality of Life.

Ledertoug, M. M. (2016). Strengths-based learning - Children's Character Strengths as a means to their learning potential. PhD thesis, Submitted to DPU/Aarhus University, Denmark.

Lickona, T., Schaps, E., \& Lewis, C. (2007). CEP's Eleven Principles of Effective Character Education. Washington, DC: Character Education Partnership.

Lottman, T. J., Zawaly, S., \& Niemiec, R. (2017). Well-being and well-doing: Bringing mindfulness and character strengths to the early childhood classroom and home. In Positive Psychology Interventions in Practice (pp. 83-105). Springer International Publishing.

Mighty Oaks. 2017. Why character education is essential in today's world. https://www.mightyoaks.edu.hk/eng/event/why-character-education-isessential-in-today-s-world

Noddings, N. (2015). The Challenge to Care in Schools, 2nd Edition. Teachers College Press.

O'Connor, M., \& Cameron, G. (2017). The Geelong grammar positive psychology experience. In E. Frydenberg, A. J. Martin, \& R. J. Collie (Eds.), Social and Emotional Learning in Australia and the Asia-Pacific (pp. 353-370). Singapore: Springer.

Oppenheimer, M. F., Fialkov, C., Ecker, B., \& Portnoy, S. (2014). Teaching to strengths: Character education for urban middle school students. Journal of Research in Character Education, 10(2), 91-105.

Pala, A. (2011). The Need for Character Education. International Journal of Social Sciences and Humanity Studies , 3(2): 23-32.

Park, N., \& Peterson, C. (2009). Strengths of character in schools. In Furlong, M. J., Gilman, R., \& HuebnerE. S. (Eds.). Handbook of Positive Psychology in Schools, Routledge, pp. 65-76.

Proctor, C., Tsukayama, E., Wood, A. M., Maltby, J., Eades, J. F., \& Linley, P. A. (2011). Strengths gym: The impact of a character strengths-based intervention on the life satisfaction and well-being of adolescents. The Journal of Positive Psychology, 6(5), 377-388.

Quinlan, D. M., Swain, N., Cameron, C., \& Vella-Brodrick, D. A. (2015). How 'other people matter' in a classroom-based strengths intervention: Exploring 
interpersonal strategies and classroom outcomes. The Journal of Positive Psychology, 10(1), 77-89.

Rashid, T., Anjum, A., Lennox, C., Quinlan, D., Niemiec, R. M., Mayerson, D., \& Kazemi, F. (2013). Assessment of character strengths in children and adolescents. In C. Proctor \& P. A. Linley (Eds.), Research, Applications, and Interventions for Children and Adolescents (pp. 81-115). Dordrecht: Springer.

Ruark, B. A. (2018). How to Build a 36-Week Character Education Curriculum. https://www.mentoringminds.com/wp-content/uploads/36-WeekCharacter-Curriculum.pdf

The Jubilee Centre for character $\mathcal{E}$ virtues. (2017). A Framework for Character Education in Schools. Birmingham: University of Birmingham.

Walters, S. (2012). Character Education A Literature Review. Temescal Associates

Waters, L., Barsky, A., Ridd, A., \& Allen, K. (2015). Contemplative education: A systematic evidence-based review of the effect of meditation interventions in schools. Education Psychology Review, 27(1), 103-134.

World Economic Forum. (2015). New vision for education: Unlocking the potential of technology. British Columbia Teachers' Federation.

Zurqoni, Retnawati, H., Arlinwibowo, J., \& Apino, E. (2018). Strategy and implementation of character education in senior high schools and vocational high schools. Journal of Social Studies Education Research, 9(3), 370-397. 